\title{
Imagens (in)atuais: sentidos emergentes no vídeo da reunião ministerial
}

\section{Tiago Segabinazzi}

Universidade do Vale do Rio dos Sinos, Programa de Pós-Graduação em Ciências da Comunicação, São Leopoldo, RS, Brasil

ORCID: https://orcid.org/0000-0003-0565-6941

\section{Ronaldo Henn}

Universidade do Vale do Rio dos Sinos, Programa de Pós-Graduação em Ciências da Comunicação, São Leopoldo, RS, Brasil

ORCID: https://orcid.org/0000-0002-3741-2936

\section{Adriana da Rosa Amaral}

Universidade do Vale do Rio dos Sinos, Programa de Pós-Graduação em Ciências da Comunicação, São Leopoldo, RS, Brasil

ORCID: https://orcid.org/0000-0001-9159-2352

\section{Resumo}

O artigo propõe-se a desenvolver uma análise sobre o vídeo da reunião ministerial do governo brasileiro tornado público em maio de 2020 por decisão do Supremo Tribunal Federal (STF). A partir de formulações conceituais de Vilém Flusser, em um primeiro movimento operacionaliza-se a noção de scanning, não só como metáfora para decodificação de imagens técnicas, mas como método de interação analítica com essas superfícies, associada, também, a um segundo movimento, ao cotejamento das dimensões semióticas propostas por Charles Sanders Peirce. A exploração do material permitiu experimentar como se estabelece um modelo de pensamento a partir de imagens. $O$ trabalho parte do pressuposto de que este acontecimento concentra uma série de fenômenos comunicacionais, que passam pelos processos em redes e plataformas digitais, bolhas algorítmicas e a eclosão do que se chamou de pós-verdade. Através de contradições ruidosas, a imagem evoca pensamentos mágicos, com a reificação de valores unidirecionais, mas que abrem espaços para apropriações diversas.

\section{Palavras-chave}

Scanning; Imagens; Modelos de pensamento; Reunião ministerial 


\section{Introdução}

0 presente artigo tem como objetivo estabelecer reflexões sobre alguns pontos da vigorosa obra de Vilém Flusser, no cotejamento com processos comunicacionais em rede na contemporaneidade - através dos quais o estatuto de verdade, problemático desde sempre, mas consagrado pelo jornalismo moderno de cunho positivista a partir do século XIX (MARCONDES FILHO, 1989; HENN, 2002), se desconstrói a todo instante. 0 vídeo da reunião ministerial do presidente do Brasil, Jair Bolsonaro, ocorrida no dia 22 de abril de 2020 e divulgada no dia 19 de maio do mesmo ano, por decisão do Supremo Tribunal Federal (STF), é emblemático, na perspectiva de que concentra, na superfície de suas articulações, uma sucessão de acontecimentos, que passa pela facada desferida ao ainda candidato, na eleição de 2018, e expande-se pela explosão do que se designa como fake news ou desinformação ao longo desse tecido político e social.

0 processo de scanning, não só como metáfora para decodificação de imagens, mas como método, será operacionalizado na tentativa de extrair de trechos dessa reunião inferências de possíveis sentidos mobilizados. Busca-se, também, aproximações conceituais na interface entre imagens técnicas, pensamento diagramático e o campo simbólico.

Na perspectiva de Flusser (2011b), as imagens técnicas sinalizaram uma mudança da história linear, escrita e lida linha por linha, para o que ele designa como pós-história, em que a varredura de imagens (scanning), operacionalizada na superfície e de forma não linear, designa a lógica de pensamento da sociedade. Ao mesmo tempo, os processos, postos deste modo, problematizam o enunciado mcluhaniano de que "o meio é a mensagem": nessa proposta, o meio é um dos componentes do mundo das mensagens. Integra um conjunto de objetos que fornece um loop de mensagens fenomenológicas. E o vídeo constituiria o meio ideal para transmitir o que Flusser entendia como a Teoria do Gesto Humano. Isso porque ele situa-se no mesmo continuum de tempo/espaço em que se eclode o fenômeno concreto do gesto humano, mesmo considerando-se que ele deve adaptar-se ao maquinário (SCHEWNDER, 2018).

Essa percepção, conforme se verá na sequência, aproxima as ideias de Flusser com a categoria fenomenológica da Secundidade desenhada por Charles Sanders Peirce (2002): um processo de representação que pressupõe uma conexão com a concretude do mundo, nesse caso, através das imagens. Processo esse que pode ser convertido em diagramas, em que se situaria o scanning flusseriano. Como essas dinâmicas não prescindem da categoria da 
Terceridade, na qual os sentidos se configuram nas suas diversas fundamentações, defendese que o scanning pode se converter em método que sistematiza várias camadas de sentidos, em toda a extensão da gestualidade implicada nas superfícies que um vídeo, como o da reunião ministerial, apresenta. É a partir desse pressuposto que se situa o gesto analítico deste artigo: percorrer o vídeo como o olhar varre uma imagem na perspectiva do scanning de forma não linear.

0 acontecimento em tela, em alguma medida, vem no bojo de transformações ocorridas nas últimas décadas em que assistimos à emergência de narrativas alternativas às mídias tradicionais, ao mesmo tempo em que com elas, ou através delas, geraram complexos processos de convergência. Tudo isso graças à larga adoção de ferramentas para formas de comunicação horizontalizadas - as chamadas mídias sociais -, a popularização de sites, blogs e demais formatos enquanto canais informativos, além da ampliação do trabalho amador no ambiente comunicacional.

Paralelo a isso - e também como impulso e resultado desta produção comunicacional -, o universo conectado se revela heterogêneo, com visões de mundo, culturas ou tribos a conflitar suas narrativas, a se incompreender - uma incomunicação, como diz Wolton (2010), que resulta em "guetos belicosos", ao aglutinar pessoas com pontos de vista em comum. 0 problema da alteridade se coloca: ao mesmo tempo em que o outro, o diferente, está mais próximo para reunir pontos de vista em comum, também se encontra mais distante separado devido à imagem que traz, em sua manifestação e sua tentativa de preservação identitária. Como acentua Ricoeur (2005), quem fala tem a intenção de que outro saiba dessa intenção. Isso levaria a um encontro que, para superar o dilema da incomunicabilidade, só se daria, conforme defende Resende (2009), através das brechas, aparentemente fugidias nas estruturas das bolhas.

Uma das facetas desta conjuntura são os movimentos socioculturais, que, dentre outras dinâmicas, motivaram a produção e a circulação de conteúdo ideológico-partidário nas redes, ao mesmo tempo em que lhes forteleceram. O Brasil - e não apenas o Brasil - tem reestabelecido, com os processos em rede, divisões políticas acirradas nos últimos anos, que contribuíram para a formação dessas bolhas discursivas, que reforçam posicionamentos já assumidos por grupos diversos. Ao mesmo tempo, há toda uma construção de sentidos reduzida ao termo polarização. Por estarem em uma disputa semiótica, além desses grupos construírem uma narrativa própria, buscam invalidar aquela considerada inimiga: um fenômeno comum são as campanhas de difamação, frequentemente na forma de fake news. 
Para além dos interesses pontuais - como ganhos financeiros (ALCOTT; GENTZKOW, 2017) ou eleitorais (RECUERO; GRUZD, 2019) -, notícias falsas se associam a pressupostos morais e contribuem para a solidificação de uma "verdade". Além de serem entendidas como uma forma da difamação, estas fakes também se mostram como veículo de uma visão de mundo que precisa de correspondência.

A produção de uma verdade se dá a partir de uma posição moral que a sustente, a explique e lhe dê razão. Um ambiente polarizado contribui, conforme Lazer et al. (2018), para uma menor tolerância a ideias diferentes das que seu grupo acredita e favorece a aceitação a notícias que sejam "ideologicamente compatíveis". "Tempos difíceis" e "tumultos sociais" são apontados por Tandoc Jr., Wei Lim e Ling (2018) como condições propícias para que se acredite em informações que confirme a distância ou inimizade em relação a outro grupo que se considere como inimigo. A proliferação de conteúdos duvidosos ou notadamente falsos é comumente associada aos grupos fechados, de crenças arraigadas e pouco contraditórias, em que, a partir de preconceitos e certezas, opera o que é chamado de "viés de confirmação": a tendência de acreditar naquilo que reforce sua narrativa de mundo. Esse fenômeno ocorre no contexto de uma sociedade em que o software (MANOVICH, 2013) ocupa um lugar central e já se tornou tão natural quanto invisível, como de resto todos os dispositivos online no contexto da plataformização (VAN DIJCK, POELL; DE WALL, 2018).

Tal momento, em que informações contraditórias são colocadas, por vezes é entendido como "era da pós-verdade" - não apenas pela prevalência de inclinações afetivas e predisposições morais acima dos "fatos", mas também pela sensação de não haver uma referência absoluta ou uma narrativa que dê conta da realidade complexa em que nos encontramos.

Esta insuficiência de uma narrativa unívoca que serviria como referência para explicar a realidade pode ser entendida a partir do que Vilém Flusser designou como a "crise dos textos": tal condição implicaria num colapso do mundo histórico e linear - e, com isso, contribuiria com o desentendimento de narrativas. Apesar de presenciarmos o fenômeno recente da fácil circulação de informações falsas - tomadas como contraposições às "mentiras da imprensa" e, até mesmo, da ciência - apontamos, ao evocar o ocaso da leitura linear, especificamente para a incomunicação entre leituras divergentes. A comunicação não seria mais capaz de dar conta dos pensamentos e dos conceitos que temos sobre o mundo, por isso outros códigos vêm sendo elaborados, como a emergência das imagens técnicas, que povoam 
o mundo pós-histórico. 0 entendimento linear, presente nos textos, é enfraquecido diante da possibilidade de uma leitura múltipla a partir de imagens.

Uma situação pede uma leitura, uma versão. Esta conjuntura de elementos acessível ao olhar, é um uni-verso disponível: a realidade está para ser lida, interpretada; entretanto, ao invés da captura semiótica seguir um caminho unívoco, as possibilidades de apreensão deste objeto dinâmico se mostram diversas - arbitrárias, divergentes e até incongruentes. A noção de varredura, de scanning, em Vilém Flusser, a partir de um olhar circular que privilegia idas e vindas em elementos díspares de uma imagem, se mostra pertinente como entendimento das leituras conflitantes de uma situação - um mesmo objeto disponível ao(s) olhar(es).

\section{Textos e leitura linear, imagens e relações mágicas}

Na perspectiva flusseriana, o alfabeto e a popularização da escrita introduziram após um tempo "mítico", em que as pessoas pensavam de uma forma "pré-histórica" - uma nova forma de pensar: "histórica", linear. O pensamento ocidental pode ser considerado histórico por conceber o mundo em processos, codificado em forma de "linha" - que ordena uma cena, uma situação, numa narrativa. Sua estrutura é uma linha unidimensional, unidirigida, que implica um modo causal de se conceber o mundo. "Ela 'explica' a cena na medida em que enumera clara e distintamente (clara et distincta perceptio) cada símbolo isolado" (FLUSSER, 2013, p. 133).

Para se decifrar um texto, o campo visual precisa deslizar ao longo da linha e, somente no final, integralizar a mensagem - processo que exige síntese, a sincronização da diacronia. O efeito seria uma nova experiência temporal, "a experiência de um tempo linear, de uma corrente do irrevogável progresso, da dramática irrepetibilidade, do projeto, em suma, da história" (FLUSSER, 2013, p. 133). É a partir dessa perspectiva que o autor entende que a história começa com a escrita - não porque ela grava os processos, mas porque transforma as cenas em processos: produz, assim, consciência histórica.

O caráter unidimensional das linhas e, consequentemente, dos textos faz com que uma leitura se imponha como única possibilidade de entendimento - e de forma de pensar sobre o mundo. As linhas, que formam um texto, se referem não diretamente às circunstâncias concretas, mas a cenas de uma imagem formada. Tal condição implica questionamentos ao caráter de exclusividade do texto em explicar o mundo - a "textolatria" moderna - e, assim, fragiliza sua hegemonia na articulação de pensamento. Emergem, então, 
as imagens como modelos de pensamento - um pensamento "pós-histórico", que tem uma forma própria de se estabelecer. Conforme Flusser (2013), as imagens permitem um "espaço interpretativo" aos seus receptores, por não serem um apanhado de símbolos com significado inequívoco: não são como as cifras, denotativas, mas "símbolos conotativos". A imagem é uma "superfície sobre [a qual] circula o olhar" (FLUSSER, 2011a, p. 102); e/ou "superfície que pretende representar algo" (FLUSSER, 2011a, p. 21); e/ou "superfície significativa na qual as ideias se inter-relacionam magicamente" (FLUSSER, 2011, p. 6); e/ou "uma imagem é uma superfície cujo significado pode ser abarcado num lance de olhar: ela 'sincroniza' a circunstância que indica como cena" (FLUSSER, 2013, p. 131). Ali, na superfície, há símbolos organizados em um código que permite que o "receptor" decida em qual deles repousar o olhar; está espalhada a informação a ser decifrada por uma varredura - o scanning. Aqui há uma diferença condicionante no processo de pensamento: a varredura dos olhos que pode seguir caminhos específicos e irregulares, conforme Flusser (1997):

[...] o olho tem certa autonomia e pode seguir seu próprio caminho. É por essa razão que a mensagem contida em uma imagem é necessariamente conotativa. Uma imagem pode ser interpretada por cada receptor à sua maneira. Isso, é claro, tem a vantagem de que a mensagem se torna cheia de significado, mas a desvantagem é que a mensagem nunca é clara e distinta. É sempre, até certo ponto, confuso. [...] 0 olho pode retornar a qualquer elemento da imagem a qualquer momento. Assim, a diacronização da sincronicidade da imagem é circular. (FLUSSER, 1997, n.p. tradução nossa). ${ }^{1}$

Ao vaguear o olhar pela superfície de uma imagem, relações temporais e significativas são estabelecidas entre os elementos que a compõem, pois um é visto após o outro - porém, num percurso não linear. Este vaguear é circular, pois contempla elementos já vistos com a possibilidade de retorno do olhar para elementos preferenciais, que passam a ser centrais e portar significados. Dali resulta o significado, que é síntese das intencionalidades do emissor e do receptor.

É o olhar que estabelece as relações significativas entre os elementos. Quando o olhar é circular, as relações estabelecidas são da ordem da magia, ao contrário do linear, que estabelece relações causais entre os eventos: "No tempo linear, o nascer do sol é a causa do

\footnotetext{
1 No original: "But the eye has a certain autonomy, and it may follow its own path. It is for this reason that the message contained in an image is necessarily connotative. An image can be interpreted by every receiver in their own way. This, of course, has the advantage that the message becomes full of meaning, but the disadvantage is that the message is never clear and distinct. It is always, to some extent, confused. [...] The eye can return to any element of the image at any time. Thus, the diachronization of the synchronicity of the image is a circular one".
} 
canto do galo; no circular, o canto do galo dá significado ao nascer do sol, e este dá significado ao canto do galo" (FLUSSER, 2013, p. 23). Com isso, Flusser (1997) entende que a explicação linear de uma imagem é impossível: não há causa e efeito - ou, ao menos, não uma relação necessária: “[...] você não pode dizer que o galo canta porque o sol nasceu ou que o sol nasce porque o galo cantou. Ambas as explicações são boas, o que é típico do pensamento mítico" (FLUSSER, 1997, n. p.). Para compreender uma situação, é preciso levar em conta seu caráter mágico - esta possibilidade de um olhar circular nos elementos que a compõem.

Chamamos atenção para a forma de leitura e de pensamento, a varredura, como gesto que não se limita à superfície imagética, mas que se espalha para uma cultura pós-histórica que substitui processos por cenas. Com o scanning podemos entender uma situação - tal qual será feito no vídeo da reunião ministerial.

Em um jornal, por exemplo, o olhar que percorre as páginas - que passa dos textos que explicam cenas para as fotos que as ilustram - também estabelece relações específicas entre seus elementos que não são relações de causa e efeito, mas mágicas, de eterno retorno: “[...] o artigo é lido em função da fotografia, como que através dela. Não é o artigo que 'explica' a fotografia, mas é a fotografia que 'ilustra' o artigo. Este só é texto no curioso sentido de ser pré-texto da fotografia" (FLUSSER, 2011a, p. 80).

As postulações de Flusser problematizam a dimensão inerente à condição humana, estabelecida na irrecusável mediação entre signos e realidade: nosso acesso ao mundo só se dá nesse processo, de naturezas e matizes das mais diversas, que dependerão de complexas relações fenomenológicas, como formulou Charles Sanders Peirce (2002). Reza sua teoria que o signo é sempre algo distinto do objeto a que se vincula. Ao mesmo tempo, o signo sempre representa o objeto de forma parcial, incompleta. Por maior que seja o vínculo conectivo entre signos e objetos, como no caso das imagens técnicas, existe uma distinção definitiva entre essas instâncias, de natureza tanto lógica quanto ontológica.

Por outro lado, o signo, independente da sua natureza ou fundamento, nunca está vinculado a um único objeto: ele pode expressar um feixe de relações, que passam por códigos constituintes, ideias, conceitos e até mesmo imaginação (HENN, 2018). Só completam-se, como signos, na medida em que geram interpretantes em uma mente, ou rede de mentes, através da qual toda essa cadeia de objetos vai se atualizando: dessa perspectiva que se pode afirmar que os signos também criam o mundo.

De forma semelhante, em Flusser, a informação não apenas remete a algo, mas se trata de uma coisa em si: ao mesmo tempo em que informação mostra algo, faz ver algo da 
forma que a informação propõe. As imagens são tanto mapas de entendimento quanto biombos: “Imagens são mediações entre homem e mundo. 0 homem 'existe', isto é, o mundo não lhe é acessível imediatamente. Imagens têm o propósito de lhe representar o mundo. Mas, ao fazê-lo, entrepõem-se entre mundo e homem" (FLUSSER, 2011a, p. 23). Por isso - por não se poder acessar o mundo imediatamente e pela incontornabilidade da mediação (GUMBRECHT, 2010) - é que as imagens são mais do que representações do mundo: "essas novas imagens são agora uma articulação do pensamento. Não são cópias, mas projeções, modelos" (FLUSSER, 1988 ). São conceitos. Conforme Seligmann-Silva (2018), as imagens não significam mais o mundo - o criam. Há no conceito, diz Flusser (2013), uma captura do fenômeno para tê-lo sob controle:

Galileu não descreveu a fórmula da queda livre, mas a inventou: foi experimentando uma fórmula atrás da outra até que o assunto da queda dos corpos graves se enquadrasse. Portanto, a geometria teórica (e a mecânica teórica) é um design ao qual submetemos os fenômenos para poder tê-los sob controle. (FLUSSER, 2013, p. 190).

Há ali, aparentemente, desencaixe e contradição: o percurso do olho sobre uma imagem não é necessariamente o mesmo, logo, o uni-verso poderá ter multi-versões. Entretanto, a versão proposta, unívoca, sequestra a possibilidade de entendimento do universo, que é múltiplo, para este verso, que é uno. Ao criar um entendimento unívoco - que pode ser canalha, antiético - sobre este multiverso, há também a criação do próprio universo enquanto canalha, antiético - tanto por propor este tipo de interpretação quanto por trazer estes elementos ao real enquanto sua composição.

Ao tratar do caráter aparentemente não simbólico e objetivo das imagens técnicas, Flusser recupera a ideia ilusória advinda da perspectiva renascentista (MACHADO, 1984) do quadro como uma transparência, uma janela aberta para o mundo. No clássico texto em que utiliza a metáfora da caixa-preta (FLUSSER, 2011b), o autor percebe na câmera fotográfica, ou qualquer outro dispositivo produtor de imagens, a concentração codificada de conceitos científicos que se expressam nos resultados dos processos sem que os usuários (designados por ele como funcionários) tenham qualquer noção dessa dimensão epistemológica do ato de fotografar. Tal transparência, no fundo, bastante nebulosa, encobre não só essa carga conceitual codificada, mas visões de mundo historicamente dadas. Mas são tais visões que, 
para Flusser (2011a, p. 29-30), são acionadas: "Quando critica as imagens técnicas (se é que as critica), não o faz enquanto imagens, mas enquanto visões do mundo".

Curiosamente, haveria mais objetividade na representação pelas imagens técnicas do que pela cultura escrita - porque o mundo representado estaria mediado pelas imagens, visto através delas e da lógica por elas proposta. Remagicização da sociedade que, segundo Flusser (2011a), é uma nova magia, entendida como de segunda ordem, que não precede, mas sucede à consciência histórica, conceitual, desmagicizante. Um feitiço abstrato que ritualiza outros tipos de modelos, não mais mitos e sim, programas.

A partir do momento em que "[...] imagem e mundo se encontram no mesmo nível do real: são unidos por cadeia ininterrupta de causa e efeito, de maneira que a imagem parece não ser símbolo e não precisar de deciframento" (FLUSSER, 2011a, p. 30), a realidade, multiverso, não pode ser outra coisa a não ser aquilo que a possibilidade de entendimento que tal versão unívoca abriu. Por isso esta versão, esta imagem, seria aparentemente objetiva - não haveria uma "linha ideológica": "Elas [imagens técnicas] são dificilmente decifráveis pela razão curiosa de que aparentemente não necessitam ser decifradas" (FLUSSER, 2011, p. 30).

Com as imagens propondo entendimentos conceituais prontos, é prescindível pensar conceitualmente: bastaria acessar as imagens. Por isso - pela perspectiva de que a realidade se transforma em uma cena - emerge a oportunidade para vê-la como uma situação a ser varrida. Ao se levar em conta o olhar circular que faz um percurso irregular sobre uma imagem, o caráter mágico extrapola o domínio da imagem e pode ser entendido como forma de entendimento do mundo, que é transformado em cenas. A imagem enquanto realidade é outro motivo pelo qual é possível de se convocar o olhar circular como possibilidade de entendimento de uma situação, tal qual uma imagem.

\section{0 scanning como proposta conceitual-metodológica}

Assim como a superfície de uma imagem, a situação em que nos encontramos nas redes sociais é um misto de ação com reação: procuramos coisas, nos deparamos com outras, e nosso olho percorre por elas, faz idas e vindas, e escolhe os elementos mais interessantes mas escolhe entre os elementos disponíveis para se escolher, a partir da arquitetura algorítmico-informacional em que nosso olho se sente "livre" para circular. 
Uma situação, diz Flusser (2011a, p. 5-6), é uma "cena onde são significativas as relações-entre-as-coisas e não as coisas-mesmas" e o scanning ${ }^{2}$ refere-se ao "movimento de varredura que decifra uma situação" (FLUSSER, 2011a, p. 5-6). 0 que interessa neste movimento do olhar que "vagueia pela superfície da imagem" é perceber relações entre os elementos que a compõem.

O scanning - como método e como metáfora é a leitura de uma situação da mesma forma que o olhar circular percorre uma imagem - "livremente". De forma semelhante, Nehama Lewis (2017) propõe que a prática de scanning seja pensada como um modelo teórico-metodológico de efeitos de busca de informações. Para ela,

A pesquisa sobre scanning de informações foca nas informações que as pessoas escolhem assistir tanto quanto em seus efeitos. Essa conceituação permite comunicação não-intencional como a que emerge a partir de encontros incidentais com a informação. Esses encontros podem disparar um interesse pré-existente em um tópico particular ou acender a chama de um novo interesse que incita o scanning de informaç̧ões. (LEWIS, 2017, p. $6)$.

Apesar de destacar a questão incidental do scanning, a autora entende que o scanning vai além disso por conta das noções de captura e arquivamento relacionadas à prática e sua relação com as mediações técnicas/tecnológicas. Segundo Lewis (2017, p. 6), "scanning foca mais especificamente na decisão em assistir às informações que encontramos ao longo das rotinas de usos de mídia e se distingue de uma busca ativa" .

A autora cita diversos exemplos focados na relação televisão e acontecimentos políticos para explicar o scanning como modelo mental de análise, o que se torna ainda mais claro para o exercício proposto pelo presente ensaio. Dessa maneira, ampliamos a percepção do scanning para uma lente intencional que nos ajuda a montar o quebra-cabeça metodológico de análise da reunião ministerial a partir da emergência de suas imagens enquanto mobilidades textuais, que contemplam os vazios potencialmente informativos suplantados por imagens de fundo mítico ou aparentemente inequívoco.

Conforme será tratado ao longo do artigo, no vídeo analisado emergem palavrasimagens abstratas - como "liberdade", "valores", "luta" - que são acionadas a partir de uma

\footnotetext{
2 Optamos por não traduzir o termo scanning, uma vez que ele não possui correlatos em língua portuguesa e a própria palavra é um neologismo que já carrega em si mesma uma vinculação à materialidade dos aparelhos técnicos que a designam: o scanner. De acordo com o Longman Dictionary of Contemporary English (SCANNING, 2005, p. 1463), scanning significa "examinar uma área com atenção, mas de forma rápida, geralmente porque você está procurando por uma pessoa ou coisa em particular". 0 dicionário também acrescenta que em relação ao scanning feito através de computador, ele permite um arquivamento do documento ou imagem escaneada estabelecendo assim uma relação com a memória.
} 
certa autossuficiência contida em cada uma delas - como se não precisassem se contextualizar na reunião, mas bastassem ser ditas para criar uma aparência de credibilidade aos seu enunciadores.

As postulações de Flusser encontram ressonância do que se pode inferir da complexa arquitetura semiótica formulada por Peirce, que tem como base fundante sua fenomenologia phaneroscópica, sintetizada desta forma por Ivo Ibri (1992): a primeridade, inscrita na capacidade de ver (que geram os signos que funcionam como tal por conta de suas qualidades positivas); a secundidade, que se refere à capacidade de coletar incidências sobre determinados aspectos (em que despontam os signos que funcionam como tal por designarem objetos singulares, concretos); e a terceridade, que transforma o aspecto como geral e pertinente a todo fenômeno (que contemplam os signos cujo caráter representacional é arbitrário, cujos objetos são de natureza geral).

Essas categorias, no entanto, são extremamente porosas, e, entre estas formas, que Peirce entendia como sendo "puras", existem inúmeras combinações. O signo nunca é somente primeiro, segundo ou terceiro. Algum aspecto das categorias se torna proeminente conforme a função que o signo exerce (FRAGOSO; HENN; REBS, 2008). Tudo que acessamos e pensamos já está inscrito em nível terceiro, seja pelo fato de que entre a dimensão primeira e segunda sempre se interporá um signo ou pela circunstância de que todo o signo já está inscrito em algum nível de codificação. As superfícies, nessa perspectiva, processariam sínteses das categorias, ostensivamente mediadas por interfaces de codificação: das linguagens em que se enunciam, dos dispositivos técnicos em que materializam e da construção binária inerente à sua natureza digital.

Uma superfície emblemática, transformada em tantas outras por diversas apropriações, estabeleceu-se no país no dia 22 de maio de 2020. Em meio à instalação da Covid-19 e suas consequências, fatais e estruturais, a gravação de uma reunião ministerial é tornada pública para que se avalie as denúncias feitas pelo ex-ministro da Justiça e da Segurança Pública, Sérgio Moro, contra o presidente Jair Bolsonaro - de tentativas de interferência na Polícia Federal a partir de interesses pessoais (A REUNIÃO, 2020).

Inserido na cena de instabilidade política e de crise governamental, agravados pela pandemia e por suas medidas de combate, questionadas popular e institucionalmente, o vídeo da reunião, além de apresentar o que foi arrolado como prova para as acusações, é uma captura mais imediata "do que aconteceu" naquele ambiente: a câmera que estava lá gravando tinha por objetivo registrar uma reunião privada, de interesse do Estado. Logo, a 
performance dos participantes deu-se nessa condição particular e casual, revelada nas falas cruas e diretas, que foram motivo de disputa interpretativa pelas redes digitais e outras instâncias mediadoras.

Um vídeo gravado, mas que não se difere tanto de uma performance ao vivo ${ }^{3}$. A gravação é arquivística, trata-se de uma reunião, se não secreta, ao menos não-pública. Estamos assistindo a algo quase "não-mediado" (ou acontecimento próximo ao nível da secundidade peirceana) - certamente, não se trata do sentido estrito deste termo, até porque há cortes de momentos com conteúdo sigiloso, mas chamamos atenção por se tratar de um conteúdo feito com certa espontaneidade: a câmera grava, mas o faz com a mesma burocracia da escrita de uma ata; o vídeo é irregular - treme, desfoca, o áudio por vezes está embargado; palavrões são ditos por diversos personagens, diversas vezes; a linguagem, como um todo, é coloquial, com analogias informais; as risadas se intercalam com momentos de exaltação e fúria do presidente e de seus ministros. Há uma estética do ruído que explicita a naturalidade de uma reunião privada - para tratar dos interesses do Estado, da coisa pública -, mas que ganhou contornos público-midiáticos somente a partir de uma quebra de sigilo. A expressão "real-oficial" parece ser adequada.

Alguns ministros se manifestaram, conforme o envolvimento de sua pasta, sobre o Plano Pró-Brasil, motivo daquela reunião. As falas tiveram tempos variados, alguns integrantes se repetiram. 0 scanning processado neste movimento de decifração concentrouse em alguns momentos que por si mesmos pediram atenção na busca da captura e estabelecimentos de relações: diagramas de sentidos possíveis.

\section{A reunião ministerial como "captura imediata"}

Bolsonaro ocupa o ponto principal da mesa, no modo como configura-se a reunião, na captura predominante da imagem e na hierarquia pré-determinada pela arquitetura. Como lembra Harry Pross (1980), através da sua existência material, os signos produzem sensação, prestígio e compreensão: a ordenação é, em si, signo. Os ocupantes desse espaço préconfigurado, na rede que estabelecem com e através desse centro, produzindo a

\footnotetext{
3 Lembramos que Diana Taylor (2013) traz os aspectos arquivísticos relacionados à performance. Embora não seja o centro da discussão no presente artigo, é importante pensarmos nessa dimensão, conforme indicada por Amaral, Soares e Polivanov (2018, p. 70): "Estamos diante de duas naturezas de investigação: uma que opera sobre a noção de performance em arquivo, ou seja, atos performáticos registrados em suportes midiáticos, passíveis de recuperação a partir do armazenamento material destes registros; outra que trata da performance em repertório, ou seja, aquela que 'desaparece', está registrada na memória dos viventes, a encenação que resultou em um estar-junto momentâneo e efêmero". A discussão de scanning e performance merece maior aprofundamento em futuros estudos.
} 
materialidade, ao mesmo tempo indicial e simbólica, dos contextos que se deslizam por essas superfícies, tensionam a ordenação, ora enfatizando-a, ora sobrepondo-a com marcas de ruído e, até mesmo, em aparente displicência, ironizando-a, como faz o vice-presidente, general Mourão, constantemente convidando à pausa do olhar para seu sorriso enigmático. Ao lado do militar, a figura do então ministro da Justiça e da Segurança Pública, Sérgio Moro, desencadeador do processo que resultou na visibilização pública do vídeo, pede outras pausas.

Mas será nas laterais da mesa que a imagem ganhará contornos pulsantes a partir das falas e gestos dos seus membros, potencialmente produzindo decodificações que se ajustam aos engajamentos prévios dos intérpretes, em diapasão que provavelmente vá da indignação feroz ao aplauso. Nas circularidades da imagem, permeadas por zigue-zagues, a ministra da Mulher, da Família e dos Direitos Humanos, Damares Alves, captada à distância, e batendo com os dedos na mesa a cada afirmação, proclama: "Esse governo tem o pilar dos valores. Não se pode construir nada neste governo sem trazer os valores" (A REUNIÃO, 2020).

Tal fala parece sintetizar o âmago cênico e ideológico do que se vê: "valores", enunciado dessa forma, pertence a uma mesma unidade que não encontraria respaldo na diversidade social. Porém, forja-se um respaldo, mesmo que de forma oportunista, já que se trata de uma visão particular da ministra adaptada às circunstâncias do momento. A proposta de liberar cassinos em resorts e mesmo a insinuação de tolerância ao turismo sexual (enfatizadas na fala do então ministro do Turismo, Marcelo Álvaro Antônio) já comprometem, mas não de todo, a mecânica disciplinar desses valores. Esta já pode ser uma divergência em relação a uma imagem aparentemente inequívoca, dos "valores" como algo de inquestionável.

Essa unidade reforça-se na fala do então ministro da Educação, Weintraub, marcada por uma sintaxe truncada:

Odeio o termo povos indígenas, odeio esse termo. Odeio. 'O povo cigano'. Só tem um povo nesse país. Quer, quer, se não quer, sai de ré. É povo brasileiro. Só tem um povo, pode ser preto, pode ser branco, pode ser japonês, pode ser descendente de índio, mas tem que ser brasileiro, pô. Acabar com esse negócio de povos e privilégio. Só pode ter um povo. Não pode ter ministro que acha que é melhor que o povo. (A REUNIÃO, 2020).

Tais expressões e palavras de ordem, da forma como são ditas - quase sem um encadeamento, mas justapostas como joias sortidas, guardadas numa caixa, prontas para serem exibidas quando for necessário mostrar seus valores -, não se diluem num texto e 
mesmo fogem do contexto daquela reunião. São palavras que não conseguem figurar libertas da imagem mítica que lhes deu origem; são elas mesmas imagens relativamente autônomas à situação (há uma pandemia e uma crise estrutural assolando o país) - por isso mesmo não se encaixam, não se decifram, só podem ser acionadas enquanto invocadas a priori: a própria situação, assim, passa a ser lida a partir destas imagens.

"Pessoas aqui em Brasília, dos três poderes, que não sabem o que é povo [...] Não sabem o que é feijão com arroz [...] Acham que o dinheiro cai do céu" (A REUNIÃO, 2020). As palavras ditas por Bolsonaro traduzem textualmente uma imagem mítica arraigada, que dificilmente pode ser contestada - seja pela realidade ser tão capturável a partir desta visão, seja pela visão ser tão forte que deva ser frequentemente lembrada para que a imagem continue servindo como lente.

"Essa cambada que tentou chegar no poder em 64, se tivesse chegado, a gente tava fodido todo mundo aí [sic]. [...] Não se pode esquecer disso" (A REUNIÃO, 2020), continuaria o presidente. Neste acionamento de imagem há uma forma de prever e de prover algo de que é preciso se esquivar, por isso são necessárias informações antes que algo possa acontecer.

Quem é que nunca ficou atrás da... da... da... porta ouvindo o que o seu filho ou a sua filha tá comentando? Tem que ver pra depois... depois que ela engravida não adianta falar com ela mais. Tem que ver antes. Depois que o moleque encheu os cornos de droga, não adianta mais falar com ele: já era. (A REUNIÂO, 2020).

Essas palavras-prontas conservam imagens que parecem ser importantes de serem reforçadas para servirem de alvo onde dirigir outras imagens-prontas, invocadas como forma, também, de construir a imagem que se quer para si - como o faz o ministro da Economia Paulo Guedes:

Nós sabemos dos valores, sabemos dos princípios, sabemos o que estamos defendendo. Nós estamos defendendo liberdade, liberdade econômica, liberdade política. Nós sabemos o que estamos defendendo. E estamos agora no meio dessa confusão derrubando a última torre do inimigo, [referindo-se aos gastos com a previdência] (A REUNIÂO, 2020).

"Não tem jeito de fazer um impeachment se a gente estiver com as contas arrumadas". (A REUNIÂO, 2020). 
A forma de garantir que um governo seja liberal é promover a imagem de um governo liberal, por meio de mais imagem - esta, delineante e performática: "Banco do Brasil é um caso pronto de privatização. [...] Tem que vender essa porra logo" (A REUNIÃO, 2020). Se há imagens para acionar para formar a si, também há imagens que se deve evitar associar a si, conforme a imagem geral que se quer formar - a preocupação de Damares é exatamente esta:

Ministro [se referindo ao recém-integrado ao governo, Nelson Teich, da Saúde], valores estão lá na sua pasta também. Neste momento de pandemia a gente tá vendo a palhaçada do STF trazer o aborto de novo para a pauta. E lá tava [sic] as mulheres que são vítimas do zika vírus vão abortar. E agora tendo o coronavírus, será que vão querer liberar que todos que tiveram o coronavírus poderão abortar no Brasil? (A REUNIÃO, 2020).

Do outro lado da cena, mas na ponta da mesa próxima ao eixo principal em que paira a figura de Bolsonaro, uma imagem divergente pode ser aceita se houver um objetivo pragmático em vista, conforme Paulo Guedes:

Todo discurso é conhecido - acabar com as desigualdades regionais [...] é bonito isso, mas isso é o que o Lula, o que a Dilma estão fazendo há trinta anos, se a gente quiser acabar igual a Dilma, então a gente segue esse caminho. [...] 0 caminho desenvolvimentista foi seguido. 0 Brasil quebrou por isso.[...] Através do excesso de gastos públicos. [...] A gente aceita. Politicamente a gente aceita. Vamos fazer todo discurso da desigualdade, vamos gastar mais, precisamos eleger o presidente. Mas o presidente precisa pensar daqui a três anos. (A REUNIÃO, 2020).

Com imagens bem estabelecidas como forma de delimitar sobre o que se está falando, é possível falar a partir destas imagens de uma forma objetiva - afinal, o objetivo está traçado por estar imagens, que serão mantidas, pois há concordância sobre todo este imaginário. Elas são acionadas também por uma questão de comunicação, de entendimento. Assim, é possível avançar objetivamente. "Não é apenas cuidar do seu ministério. É tratar da questão política. A luta pelo poder continua a todo vapor. Levantar aquela bandeira do povo não custa nada" (A REUNIÃO, 2020), disse Bolsonaro. A situação em que o país se encontra é, então, lembrada, remagicizada, e vem atender aos objetivos a partir da evocação dessas imagens, consubstanciadas na superfície.

Foi o (na época) ministro do Meio Ambiente Ricardo Salles, no lado oposto da cena protagonizada por Guedes, num ponto entre Weintraub e Damares, e com o ainda Ministro da 
Saúde, Teich, fazendo uma espécie de sombra, quem produziu a fala mais pragmática daquela reunião:

A oportunidade que nós temos, que a imprensa não tá... tá nos dando um pouco de alívio nos outros temas, é passar as reformas infralegais de desregulamentação, simplificação. [...] Tudo que a gente faz é pau no Judiciário, no dia seguinte. Então pra isso precisa ter um esforço nosso aqui enquanto estamos nesse momento de tranquilidade no aspecto de cobertura de imprensa, porque só fala de Covid, e ir passando a boiada e mudando todo o regramento e simplificando normas. (A REUNIÂO, 2020).

Trata-se da fala que teve maior encadeamento de ideias, mais linearidade; estava alinhada com a situação e com as imagens anteriormente invocadas ${ }^{4}$. Com o acionamento das imagens, que servem como objetivo, objeto de concordância, há sinergia, menos embate: alinhamento que prescindiria de imposição, apenas seguimento tático de uma estratégia contida em e mantida por tais imagens:

"Por isso que eu quero, ministro da Justiça e ministro da Defesa, que o povo se arme. Que é a garantia que não vai ter um filho da puta aparecer pra impor uma ditadura aqui" (A REUNIÃO, 2020), referia-se Bolsonaro à possibilidade de o povo resistir a medidas de governadores ou prefeitos que fossem contra a sua vontade. A sua vontade é a vontade do povo ou a vontade do presidente? É a vontade das imagens - que parecem ser anteriores e exteriores ao próprio falante, que apenas as reúne para salientar que seu discurso está colado a tais imagens fortes; de tão abstratas, estas imagens parecem irrefutáveis: são exibidas e ostentadas, numa performance de quem quer estar ao lado delas, que as persegue como quem está atrás delas.

Quem não aceitar as minhas bandeiras - família, Deus, Brasil, armamento, liberdade de expressão, livre mercado - está no governo errado. [...] É escancarar a questão do armamento aqui. Eu quero todo mundo armado! Que povo armado jamais será escravizado. (A REUNIÃO, 2020).

Ao aceitar uma imagem, se pode também falar a partir desta imagem aceita - como forma de concordância e de objetividade. Paulo Guedes, da Economia, prevendo desemprego e necessidade de investimento público, alinha-se à imagem: 
Quantos jovens aprendizes nós podemos absorver nos quartéis brasileiros? Um milhão? Um milhão a duzentos reais, que é o Bolsa Família, trezentos reais, pro cara de manhã faz [sic] calistenia [...] faz ginástica, canta o hino, bate continência. De tarde, aprende, aprende a ser um cidadão, pô! Aprende a ser um cidadão. Disciplina, [...] voluntário pra fazer estrada, pra fazer isso, fazer aquilo. Sabe quanto custa isso? É duzentos reais por mês [...] A Alemanha fez isso na reconstrução. (A REUNIÃO, 2020).

Anteriormente, Abraham Weintraub já havia deslizado pela sua síntese ideológica: “E o que me fez, naquele momento, embarcar junto era a luta pela... pela liberdade. Eu não quero ser escravo nesse país. E acabar com essa porcaria que é Brasília. Isso daqui é um cancro de corrupção, de privilégio"(A REUNIÃO, 2020). Brasília, aqui, é evocada como sinônimo de poder corrompido por essa suposta contemplação da diversidade, em contradição com o exercício de poder ali constituído. A imagem puxa para outra, extra-quadro, da arquitetura histórica da Praça dos Três Poderes, continuadamente ressignificada. E o ministro, na sua confusão sintática, coloca-se em uma missão, acionando o quadro mítico:

[...] eu não vim pra jogar o jogo. Eu vim aqui pra lutar. E eu luto e me ferro. Eu tô com um monte de processo aqui no comitê de ética da presidência. Eu sou o único que levou processo aqui. Isso é um absurdo o que tá acontecendo aqui no Brasil. A gente tá conversando com quem a gente tinha que lutar. A gente não tá sendo duro o bastante contra os privilégios, contra o tamanho do Estado e é o... eu realmente tô aqui de peito aberto, como cês [sic] sabem disso, levo tiro... odeio... odeio o partido comunista. (A REUNIÃO, 2020).

Neste momento o vídeo é cortado por decisão judicial. Mas a imagem síntese centrase em Bolsonaro (Figura 1), descolando-se de qualquer objetividade administrativa, para se deter no mítico:

[...] quando a Câmara faz lá dentro uma homenagem a Che Guevara, a Mao Tse-Tung e tudo mais, não tem problema nenhum. Quando o Partido Comunista do Brasil faz suas convenções e idolatram lá Fidel Castro, entre outros, não tem problema nenhum. Quando um coitado levanta uma placa de Al-5, que eu tô me lixando para aquilo, porque não... porque não existe AI-5. Não existe. (A REUNIÃO, 2020). 
Figura 1 - Bolsonaro ao centro da reunião

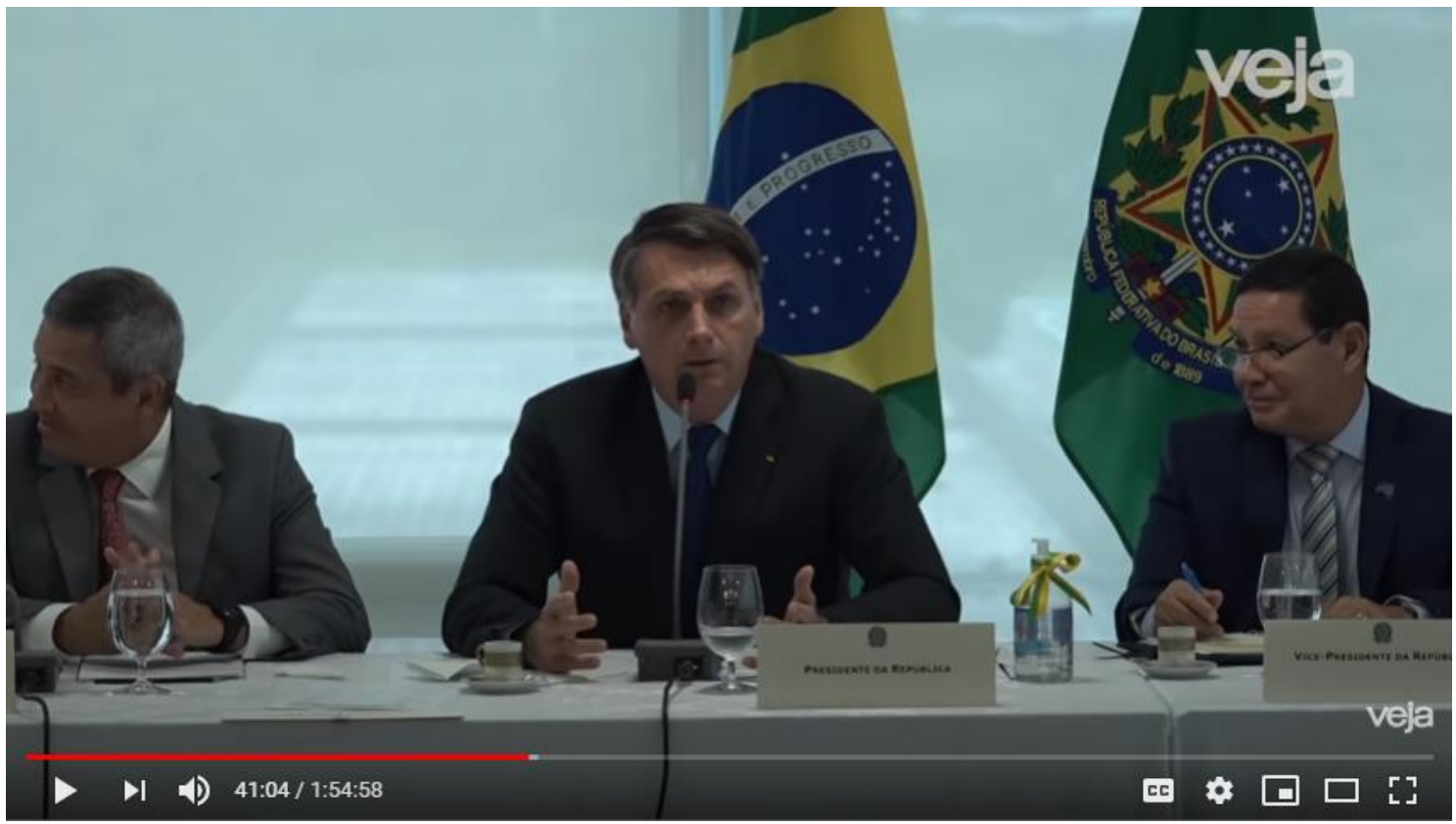

Fonte: A reunião de Bolsonaro com ministros em 22 de abril (2020).

Ao mesmo tempo em que invoca imagens de 50 anos atrás, Bolsonaro diz que não existe mais AI-5, porque é coisa do passado. "AI-5 não existe, não existe ato institucional no Brasil mais. É uma besteira" (A REUNIÃO, 2020). Não existe mais porque o tempo passou entretanto, esse tempo passou apenas para o tempo histórico, linear e progressivo. No modelo de pensamento pós-histórico, do eterno retorno, as imagens permanecem atuais porque são recuperadas prontamente - num relampejo, o olhar circular sincroniza as imagens aparentemente separadas, distantes, e reordena a situação a partir de seu sentido mágico. As ações - falas e performances - contemporâneas que podem parecer sem sentido, têm seu sentido abarcado pelo extemporâneo de uma imagem continuamente evocada.

A recuperação constante e insistente de imagens para si e para o inimigo, imagens prontas e assim mantidas como eternas, é a forma de dar razão, de fazer sentido, ao que é dito e ao que é performado: com a realidade lida, remagicizada, a partir destas imagens, há sentido, sentido mítico. Se tal performance se descola do que a situação pede, ainda se mantém intimamente ligada ao que pedem as imagens; ao serem acionadas, também, as imagens passam a criar a situação - com elas e a partir delas - e a atuação passa a ser significativa, a fazer sentido, para uma imagem re-atualizada e numa situação magicizada pós-imagem - quando a situação é lida a partir das imagens acionadas. 0 que poderia parecer 
descontextualizado e descolado da situação se torna significativo pelo uso das imagens extemporâneas, inatuais.

Em vários momentos desta reunião a palavra liberdade foi invocada pelos participantes - não apenas pronunciada, mas mesmo invocada: como algo que é superior, absoluto e inequívoco. Exatamente por passar esta imagem de algo incontestável é que a liberdade surge como imagem sólida - tal qual suas quatro sílabas bem pronunciadas -, que não se dilui no texto que a enuncia, nem no contexto que compõe a situação, mas se mantém firme enquanto acionada por uma imagem.

Há uma certa imagem de liberdade pela qual é lida esta palavra. Mesmo sendo uma imagem, o que se busca ali é lhe impor um sentido linear e unívoco - com isso esta palavrapronta pode ser usada como moeda comum: e tal qual uma moeda, passa a ser mais importante que a relação para a qual é invocada. Torna-se a própria coisa, impõe seu sentido e sua imagem a ponto de não apenas contradizer, mas negar o que lhe está ao redor.

O ex-ministro Weintraub luta pela liberdade de fazer dos povos apenas um só - o brasileiro: “quer, quer, se não quer, sai de ré”. A prisão, que sugeriu, está para os membros do STF como para os governadores e prefeitos citados por Damares - que se preocupa também se poderia se "liberar geral" o aborto. Paulo Guedes diz saber o que está defendendo: "liberdade, liberdade econômica, liberdade política" - e para por aí a enumeração das liberdades que lhe surgem; a forma do governo estar livre da possibilidade de impeachment é estar com as contas em dia - uma das medidas facilmente acionáveis, e citada, é que um milhão de jovens estejam nos quartéis por duzentos reais por mês aprendendo disciplina e trabalhando voluntariamente na "reconstrução" do país. "A vontade deve ser soberana para que o povo não seja escravizado", diz Bolsonaro. 0 armamento vira instrumento de exercício da liberdade de aceitar suas condições - para não ser escravo, mas para escravizar. Quem não “aceitar as minhas bandeiras [...] está no governo errado" (A REUNIÂO, 2020).

A palavra liberdade aparentemente se descola das situações e do contexto em que é acionada, mas tem seu sentido perpassado e estabelecido por um certo tipo de imagem, construído e recuperado em diversas oportunidades ao longo da reunião. 0 sentido é constituído de uma forma mítica, ao trazer elementos extemporâneos, mas atualizados pela liberdade do olhar circular, que percorre irregularmente e privilegia de forma díspar onde deve repousar a atenção. 


\section{Considerações finais}

0 que buscamos neste artigo foi chamar atenção para a aparente contradição explicitada na reunião ministerial a partir do acionamento de imagens míticas: ao mesmo tempo em que uma imagem forte sugere um significado inequívoco - depois da invenção da alavanca, um pedaço de pau passa a ser visto com a iminência de adquirir tal função ou significado, diz Flusser (2012) -, as imagens também são parte de uma construção possível da realidade - sempre complexa e multifacetada.

Um dos aspectos exteriorizados pelos processos comunicacionais em rede que mais chama atenção é o dissenso discursivo: às lutas político-partidárias especificamente circunscritas se aglutinam divergências de costumes, de visões de mundo. Tais discrepâncias podem se tornar conflitos ou disputas semióticas não somente por uma condição de heterogeneidade moral, mas também pela força com que uma imagem carrega uma interpretação de mundo de forma unívoca.

Pode não ser possível explicar as disputas semióticas em torno de uma mesma situação a partir da emergência em grande escala de imagens, mas é possível pensar na leitura múltipla delas como forma de entendimento para as narrativas divergentes disponíveis - e como mais um elemento do que se chama de pós-verdade.

As indicialidades imagéticas da reunião ministerial, nas circularidades que estabelecem e vinculadas às imagens evocadas pelas falas dos seus atores, transformam a cena numa plêiade de instâncias sígnicas de fundos, ao mesmo tempo mágicos e ruidosos. Seu caráter rústico, no sentido de ser um acontecimento aparentemente pouco mediado, sobrepõe-se na mesma intensidade em que emerge toda uma codificação simbólica entranhada nas processualidades dessa imagem na interface com o plano simbólico das falas: reificação de valores unívocos, apagamento de diferenças e reenquadramento das liberdades em sentidos únicos.

Neste vídeo-registro, aparentemente livre de uma mediação que lhe imporia um sentido linear, ao deixar o olhar lhe circular, percebemos a irremediável interposição de imagens, que além de construir a realidade mítica, se tornam as próprias coisas a se referir. No entanto, conforme Peirce (2002), independente da sua natureza na condição de coisa concreta ou mesmo uma ideia, os signos sempre apontam para algo que lhe é exterior, os seus objetos dinâmicos. 
A varredura das imagens nessas superfícies, como gesto metodológico, permite o acionamento e a concatenação desses objetos, que se interpõe de modo não linear. Dessa forma, o scanning flusseriano foi proposto como método, metáfora e modelo conceitual e metodológico para lermos imagens postas em circulação nos contextos em rede. A dimensão simbólica, em que a indicialidade da imagem configura as falas que dela emergem, sugere camadas de sentidos intercalados na varredura empreendida.

\section{Referências}

ALLCOTT, Hunt; GENTZKOW, Matthew. Social Media and Fake News in the 2016 Election. In: Journal of Economic Perspectives, Nashville, v. 31, n. 2, Spring, p. 211-236, 2017.

AMADO, Guilherme. Ricardo Salles extingue três bases do Projeto Tamar, de conservação de tartarugas. 0 Globo, São Paulo, 28 maio. 2020.

AMARAL, Adriana; SOARES, Thiago; POLIVANOV, Beatriz. Disputas sobre performance nos estudos de Comunicação: desafios teóricos, derivas metodológicas. Intercom, Revista Brasileira das Ciências da Comunicação, São Paulo, v. 41, n. 1, p. 63-79, 2018.

A REUNIÃO de Bolsonaro com ministros em 22 de abril. Brasil, 22 de maio de 2020.1 vídeo (60 min.). Publicado pelo canal vejapontocom. Disponível em:

https://youtu.be/nfgv7DLdCqA. Acesso em: 25 de maio de 2020.

FLUSSER, Vilém. Sobre a escrita, complexidade e as revoluções técnicas. [Entrevista cedida a]: Miklós Peternák. In: European Media Art Festival. Osnabrück, set. 1988. Título original: On writing, complexity and the technical revolutions.

FLUSSER, Vilém. Sobre imagens técnicas, acaso, consciência e o indivíduo. [Entrevista cedida a]: Miklós Peternák. Munique, 17 out. 1991. Título original: On technical images, chance, consciousness e the individual.

FLUSSER, Vilém. Vilém Flusser interviewed by Miklós Peternák (1988, unpublished). [Entrevista cedida a]: Miklós Peternák. In: INTERNATIONAL VILÉM FLUSSER SYMPOSIUM \& EVENT SERIES, 6, 1997, Budapeste. Tema: Intersubjectivity: media metaphors, play \& provocation, Budapeste, mar. 1997. Disponível em:

http://www.c3.hu/events/97/flusser/participantstext/miklos-interview.html. Acesso em 18 jul. 2019.

FLUSSER, Vilém. Filosofia da caixa preta: ensaios para uma futura filosofia da fotografia. São Paulo: Annablume, 2011a.

FLUSSER, Vilém. 0 mundo codificado: por uma filosofia do design e da comunicação. São Paulo: Cosac Naify, 2013.

FLUSSER, Vilém. Post-History. Mineápolis: University of Minnesota Press, 2011b. 
FLUSSER, Vilém. 0 universo das imagens técnicas: elogio da superficialidade. São Paulo: Annablume, 2012.

FRAGOSO, Suely; HENN, Ronaldo; REBS, Rebeca. Proposta de uma taxonomia dos lugares online. In: Simpósio de Cibercultura ABCiber, 2., 2008, São Paulo. Anais [...]. São Paulo: ABCiber, 2008.

GUMBRECHT, Hans Ulrich. Produção de presença: o que o sentido não consegue transmitir. Rio de Janeiro: Contraponto, 2010.

HEINRICH, Ansgard. Networked Journalism. Londres: Routledge, 2011.

HENN, Ronaldo. Park Row: a gênese do jornalismo moderno. In: BERGER, Christa. (org.), Jornalismo no Cinema. Porto Alegre: Editora da UFRGS, 2002, p. 51-64.

HENN, Ronaldo. COM... 0 mercado de notícias: documentário e jornalismo em interfaces narrativas. In: KURTZ, Adriana; VARGAS, Heidy. (Org.). Jornalismo e documentário: diálogos possíveis. 1ed. Appris: Curitiba, v. 1, 2018, p. 41-58.

IBRI, Ivo Assad. Kósmos Noetós: a arquitetura metafísica de Charles S. Peirce. São Paulo: Perspectiva: Hólon, 1992.

LAZER, David; BAUM, Matthew; BENKLER, Yochai; BERINSKY, Adam; GREENHILL, Kelly; MENCZER, Filippo; METZGER, Miriam; NYHAN, Brendan; PENNYCOOK, Gordon; ROTHSCHILD, David; SCHUDSON, Michael; SLOMAN, Steven; SUNSTEIN, Cass; THORSON, Emily; WATTS, Duncan; ZITTRAIN, Jonathan. The science of fake news: addressing fake news requires a multidisciplinary effort. In: Science, [s.l.], v. 359, n. 6380, p. 1094-1097, 2018.

LEWIS, Nehama. Information Seeking and Scanning. In: RÖSSLER, Patrick Rössler; HOFFNER, Cynthia A.; VAN ZOONEN, Liesbet (Ed). The International Encyclopedia of Media Effects. New Jersey: John Wiley \& Sons, 2017. p. 734-757

SCANNING. In: LONGMAN Dictionary of Contemporary English. Essex: Pearson Education Limited, 2005.

MACHADO, Arlindo. A Ilusão Especular: introdução à fotografia. São Paulo: Brasiliense, 1984.

MANOVICH, Lev. Software takes command. New York: Bloomsbury Academic, 2013.

MARCONDES FILHO, Ciro. O capital da notícia. São Paulo: Ática, 1989.

PEIRCE, Charles Sanders. The Collected Papers of Charles Sanders Peirce. Past Masters, CD-ROM. EUA, InteLex Corporation, 2002.

PROSS, Harry. Estructura simbólica del poder. Barcelona: Gustavo Gili, 1980.

RECUERO, Raquel; GRUZD, Anatoly. Cascatas de Fake News Políticas: um estudo de caso no Twitter. Revista Galáxia, São Paulo, n. 41, maio-ago. p. 31-47, 2019. 
RESENDE, Fernando. 0 jornalismo e suas narrativas: as brechas do discurso e as possibilidades de encontro com o outro. Revista Galáxia, São Paulo, n. 18, p. 31-43, 2009.

RICOEUR, Paul. Discours et communicacion. Paris: Editions de L'Herne, 2005.

SCHWENDENER, Martha. Vilem Flusser's Severities: Phenomenology, Television, Cybernetics, and Video Art. Afterimage, Califórnia, v. 45, n. 5, sept.-oct., p. 22-28, 2018.

SELIGMANN-SILVA, Márcio. Flusser e a cidade como Gesamtkunstwerk (obra de arte total). Revista Galáxia, São Paulo, n. 39, set-dez. p. 124-135, 2018.

TANDOC, Jr, Edson C.; LIM, Zheng Wei; LING, Richard. Defining 'Fake News': A Typology of Scholarly Definitions. Digital Journalism, Oxon, v. 6, n. 2, p. 137-153, 2017.

TAYLOR, Diana. 0 arquivo e o repertório: Performance e Memória Cultural nas Américas. Belo Horizonte: Editora UFMG, 2013.

VAN DIJCK, José; POELL, Thomas; DE WALL, Martijn. The Platform Society: Public Values in a Connective World. Londres: Oxford, 2018.

WOLTON, Dominique. Informar não é comunicar. Porto Alegre: Sulina, 2010.

\title{
(Not) Current images: Brazilian ministry cabinet meeting video analyzed through Villém Flusser's scanning
}

\begin{abstract}
This paper proposes the development of an analysis about one video of the Brazilian Ministry Cabinet meeting that was released online in May 2020 under the decision of the Supreme Judiciary Court. From Villém Flusser's theoretical formulations, we discuss the notion of scanning, not only as a metaphor to decodify technical images but as a method of analytic interaction with these kind of surfaces. Also, in one second operation we relate it to the semiotic dimensions proposed by C. S. Peirce. The scanning of the empirical material has alowed us to experiment how a model of thought is conceived starting from images. The work starts from the assumption that this event concentrates one series of communicational phenomena like processes in digital networks and platforms, algorithmic bubbles and the outbreak of what is so called post-truth. Through noisy contradictions, those images evoke magical thoughts and the reification of onedirectional values even though they open spaces for diverse interpretations and appropriations.
\end{abstract}




\section{Keywords}

Scanning; Images; Models of Thought; Ministry cabinet meeting

\section{Autoria para correspondência}

Tiago Segabinazzi

E-mail: tiagosegab@gmail.com

Ronaldo Henn

E-mail: henn@unisinos.br

Adriana da Rosa Amaral

E-mail: adriamaral@unisinos.br

\section{Como citar}

SEGABINAZZI, Tiago; HENN, Ronaldo; AMARAL, Adriana da Rosa. Imagens (in)atuais: o vídeo da reunião ministerial percorrido a partir do scanning de Vilém Flusser. Intexto, Porto Alegre, n.52, e-112295, jan./dez. 2021. DOI: http://dx.doi.org/10.19132/1807-8583202152.112295

Recebido em 21/03/2021

Aceito em 01/06/2021 